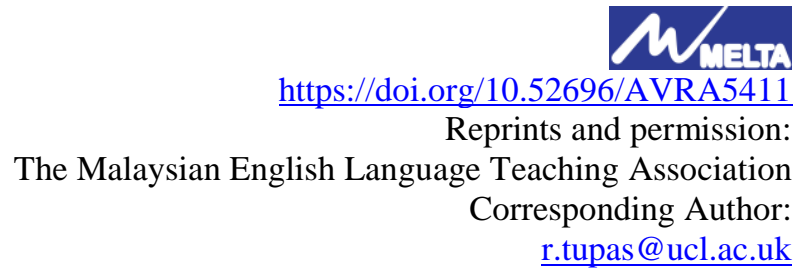

\title{
Teacher Agency Through Collaborative Expertise-building
}

\author{
Ruanni Tupas \\ Institute of Education \\ University College London
}

\begin{abstract}
Drawing on teacher agentive acts in the process of collaborative expertise-building in selects tertiary institutions in Southeast Asia, this paper maps out the conceptual configurations of teacher agency. In doing so, it avoids both the overly deterministic and individualistic views of agency by locating it within structuring conditions where individual acts are also mobilized. However, while most socially constructive views of agency focus on situated and institutional constraints of agency, this paper conceptualizes teacher agency in its broadest possible sense as historical, cultural and ideological phenomenon, arguing that agentive acts cannot merely be seen as either working for or against educational reform and transformation; rather teachers must take control of the process of knowledge production because it is by doing so that teachers can take ownership over their everyday classroom tactics and practices. Teacher agency in this sense is not simply a capacity to act but, in fact, an accomplishment of acts of producing knowledge for one's professional practice.
\end{abstract}

\section{KEYWORDS: teacher agency, materials writing, curriculum development, Southeast Asia, expertise}

\section{Introduction}

In a teacher capability-building project in curriculum development and materials design which I co-facilitated in Singapore, Indonesia, Vietnam and the Philippines, one of the most conflicted and intriguing dimensions in the generation of 'capability' among teachers is teacher agency. In its broadest sense, teacher agency refers to one's power to "make free or independent choices, to engage in autonomous actions, and to exercise judgment in the interests of others and oneself" (Campbell, 2012, p. 183). As practitioners engaged in the daily messiness of the classroom, we appear to make decisions which we call our own, and this could be facilitated by particular professional beliefs which make agentive practice possible (Biesta et al., 2015). On the other hand, 
we also casually narrate daily challenges in the way we exercise teacher agency because sometimes meant half-jokingly - we say that it really depends on whether or not our principal or school administrator is observing our class or within hearing distance from our classroom. In a sense, this tells us that what we do in the classroom is not totally our own making even if we sometimes think our decisions are totally our own.

\section{Teacher agency: Taking control of structure of knowledge production}

In this paper, I conceptualize teacher agency in its broadest possible sense as historical, cultural and ideological phenomenon. I do so by narrating and describing a collaborative expertise-building project among English language teachers in select tertiary institutions in Singapore, Indonesia, Vietnam and the Philippines during which they - through collaborative acts -- gradually took control of the production of knowledge in curriculum development. This means that I aim to address two major pitfalls in the theorization of agency that has confounded the literature thus far: "an over-socialised, macro view of agency" and "overly individualised notions of agency" (Priestley et al., 2012, p. 194). This objective to address the intriguing and slippery link between individual acts and structural conditions is nothing new. However, while such work does indeed surface the socially-mediated nature of teacher agency, the common trajectories are immediate or situated social conditions which impact or shape professional development and/or practice of teachers (Imants \& Van der Wal, 2020; Tao \& Gao, 2017; Biesta \& Tedder, 2007). Wagner et al. (2019), for example, rightly define teacher agency "framed by structures that include those that are physical or embodied, such as classroom resources or the physical spaces of schools, and generalizable procedures, such as curricular guidelines or demands driven by assessments" ( $p$. 400). This paper expands the notion of 'structures' to encompass broad cultural and historical conditions which shape teacher agency. Thus, teacher agency refers to active projects of intervention in the production of knowledge which is embedded within historical, socioeconomic and political conditions of coloniality and neoliberalism such that what is important is not so much the facilitation or the resistance to school reform or curriculum change, but rather the teachers' being able to take control of the process of the knowledge production itself through teaching and curriculum development.

In the research literature, there has been the tendency in some work to treat teacher agency as if it exists apart from the structure within which we operate as teachers (Calhoun, 2002). This structure is difficult to pin down, but it does include institutional constraints (such as the simple but concrete example above, but also policies which work against what we want and hope to accomplish in the classroom) which also implicate ideologies which help construct and manage such constraints in the first place. However, it also involves conditions beyond formal institutional boundaries such as national policies within which are embedded ideologies and practices of capitalist globalization, as well as global coloniality. They are hidden yet pervasive conditions which impact our work as teachers.

In other words, it is not just the bodies and power of school authorities which shape classroom practice. Histories, cultures and ideologies speak through and shape all aspects of our professional lives as teachers even if we seem to be acting on our own away from the prying eyes of our immediate institutions and institutional leaders. It may be that critical professional discourses and educational philosophies are necessary for teachers to develop "repertoires for manoeuvre" in the 
classroom (Priestly et al., 2012, p. 211), but this paper extends teacher agency beyond discursive considerations such as beliefs and educational philosophies by framing it within structuring historical and cultural conditions. It acknowledges that by and large there is "lack of conceptual clarity about the nature and purpose of teacher agency and change" (Pantić, 2015, 760), thus this paper aims to discuss the concept squarely in terms of taking control of the structure of knowledge production in our profession hopefully to help work towards greater clarification of the concept.

In this paper, however, I also expound how teacher agency is engaged in "necessary pedagogical tactics" (Campbell, 2012, p. 187) except that it is a profoundly historical, cultural and ideological phenomenon. In other words, while this paper moves away from purely psychological conceptions of teacher agency where teachers are invested with the capacity to act freely without social constraints (Calhoun, 2002), it also does not subscribe to an overdeterminist perspective which renders teachers as "pawns" of the system (Lasky, 2005, p. 900). Teachers as agentive professionals are invested with individual capacities to act on conditions largely beyond our control. This conception of agency draws fundamentally on Butler's (1997) theorization of agency which locates it within conditions which are larger than individual acts but upon which such acts make their unique imprint:

That agency is implicated in subordination is not a sign of a fatal self-contradiction at the core of the subject and, hence, further proof of its pernicious or obsolete character. But neither does it restore a pristine notion of the subject, derived from some classical liberal-humanist formulation, whose agency is always only opposed to power. The first view characterizes politically sanctimonious forms of fatalism; the second, naïve forms of political optimism. I hope to steer clear of both these alternatives (p. 17).

Thus, following Butler, this paper questions the use of 'teacher agency' as a way to deny or gloss over the centrality of structuring conditions which continue to shape our lives such as the coloniality of our professional practice and its embeddedness in neoliberal networks of ideologies, power and relations. This is what Butler describes above as naïve political optimism. In some scholarly quarters, the rhetorical line goes something like this: 'linguistic imperialism is a thing of the past. You see, we have evidence of teachers resisting it.' Similarly, the role of neoliberal ideas and practices in shaping classroom practice is glossed over or de-highlighted because teachers, the argument continues, have defied policies or transformed disempowering classroom practices. This paper argues that the presence of teacher resistance, defiance and power does not negate the pervasiveness of structural conditions because teachers as agents are "embedded in their contextual conditions, yet capable of transforming these conditions" (Pantić, 2015, p. 760). In the case of this paper, these contextual conditions are not simply immediately situated conditions but are, in fact, thoroughly historical, cultural and ideological conditions.

In other words, teacher agency is the power to act on and transform conditions which shape one's practice but the act of doing so is mobilized within - not outside - these conditions as well. It is a dynamic interplay of empower(ed) acts within disempowering conditions. This view, again following Butler, is neither fatalist (the structure is completely disempowering) nor naïve (individuals can exercise agency without the influence of structuring conditions). 
One way to operationalize teacher agency in the sense above is when teachers are able to take control of the structure of knowledge production in their field. In this paper, I will do so by narrating and describing my experience leading a capability-building project in materials design in Southeast Asia for teachers in higher institutions in Singapore, Indonesia and Vietnam and the Philippines where we worked on collaboratively developing our 'expertise' in writing materials in professional communication and English learning. Additionally, quotes from individual participants will also be included as appropriate. These statements come from regular reflections sought from them which were included in the quarterly reports submitted to the funding organization (see below). At the start of the project, all participants signed an agreement to allow these reflections and the materials they would produce to be used in written academic outputs.

The three-year project (conducted between 2009-2012) and funded by the Temasek Foundation Singapore aimed to help teachers develop their own materials in order to make these materials more appropriate for their own contexts of teaching and learning (see Tupas, 2014; 2020; 2021). The process was suffused with historical, cultural and ideological constraints because the structure of knowledge production in English Language Teaching (ELT) in Southeast Asia is to a large extent not conducive to producing locally-made materials if we are to listen to teachers themselves talk about their insecurities about writing their own materials. This paper tracks ways by which teachers gradually took control of the production of materials by reorienting knowledge production towards the needs of their students and classrooms and proceeded from there to construct relevant knowledge upon which would be built the materials they would produce in the end (see Kumaravadivelu, 1994; Kuchah, 2013). I have written about this project through the lens of the politics of knowledge production (Tupas, 2020; 2014) and the politics of localization (Tupas, 2021), but in this paper the focus is unpacking the nature of teacher agency. As mentioned earlier, I define it as conditioned (but not completely controlled) individual acts of resistance and intervention in the practice of the profession.

\section{The Politically and Culturally Conditioned Nature of Teacher Agency}

At any given time in the duration of the project, there were around 80 tertiary English teacher participants. The project was grounded in an understanding of use of materials in English and professional communication classrooms as culturally and politically problematic because textbooks and similar teaching resources are by and large produced by writers and scholars who are unfamiliar with the cultural nuances and diversity of hugely multilingual classrooms in Southeast Asia. Kumaravadivelu (2006) asserts that "textbook preparation and production remain a centrally controlled, globally targeted activity with very little role for local ELT professionals" (2006, p. 20), and still remains so up to this day (Al Hosni, 2015; Kazemi et al. 2017). Conceptually, we may refer to these 'foreign' materials as constitutive of the politics and ideologies of 'the global coursebook' (Gray, 2002), which is produced in traditional centers of knowledge production in the business of teaching and learning of English such as the United States and the United Kingdom and which generally espouses the cultural values of these centers and thus markets particular language teaching methods and language standards as universally applicable. In other words, the global coursebook to a large extent imposes particular worldviews, practices and teaching methodologies which do not align with the cultural sensitivities, institutional demands and learner needs of local ELT practice. 
One crucial way to address the cultural imperialism of the entire ELT global industry is to develop ways of generating knowledge about our local classrooms from which would emerge potentially relevant teaching and learning materials. Ideally, this would require 'expertise' in writing locallyproduced materials but, as will be described later, such expertise needed to emerge from engaging in projects of empowerment through collaborative work. But how does one start if the teachers themselves do not feel confident to write their own materials? As one teacher from Vietnam admitted early on: 'I don't know how to write the materials so I just get from the book' (Pham) ${ }^{1}$. ELT expertise in the region (and similar ELT contexts) is by and large defined in terms of what the teachers are not - 'native speakers', 'textbook producers' and 'knowledgeable of latest methodologies' (Llurda, 2016; Kumaravadivelu, 1994). Teachers in the region are essentially consumers of textbooks, and their classrooms laboratories for testing theories and language teaching methods developed in (Western) centers of knowledge and knowledge production (Chowdhury \& Le Ha, 2008).

Consequently, one of the key principles of the project was its commitment to expertise-building as a collaborative and grounded endeavour. However, this proved to be a great challenge: we needed to convince the stakeholders - from the funders to the teachers - that there would be no 'experts' in the project in the sense of individuals and institutions that are institutionally legitimized as knowledgeable in the field and thus invested with authority and power to 'educate' or 'train' other teachers in the rest of the world. In the uneven field of knowledge exchange and flow, the 'experts' of ELT are deemed to be those coming from centers of knowledge production such as the United States and the United Kingdom who theorize and develop methodologies from their own specific cultural contexts of teaching and learning. Coming from what Kachru (1986) refers to as inner circle countries, thus imbued with professional identities associated with white privilege and native speakership, these 'experts' travel the rest of the 'non-native English' world and preach about the 'best' practices in ELT. In recent years, 'localization' has become a buzzword (Tupas, 2021), thus making the introduction of 'new' theories and language teaching methodologies more culturally and ideologically palatable, because it essentially means "presenting a global product in different local flavors" (Kumaravadivelu, 2006, p. 15). Yet by and large the nature of knowledge and skills being 'shared' is one that is fundamentally associated with particularized or provincialized cultural sensibilities and experiences only made 'universal' by institutions of power which control the production of knowledge in the field of ELT. In this geopolitics of knowledge production, the teachers in the project (and teachers of English in the region in general) are positioned as consumers - rather than producers - of knowledge. One of the realizations put forward by some of the teachers in the project had to do with the fact that they could actually write materials in the first place. One of the Indonesian teachers put it clearly -- 'I realize that all of us can actually put materials for our students' (Santi) - which in some contexts may sound surprising because it should be self-evident that teachers write materials for their own classrooms, but it is certainly not in other cultural and institutional contexts where 'good' knowledge is produced elsewhere.

Thus, in an earlier article (Tupas, 2020), I narrated how our project, especially at the initial stages, was confronted repeatedly by questions about expertise. On the side of the funders, we needed to

\footnotetext{
${ }^{1}$ All names are pseudonyms.
} 
respond to queries about who was going to lead the project if $\mathrm{we}^{2}$, the co-Directors, would not take on the role of 'experts'. On the part of the teachers during the first few rounds of institutions, we were asked a similar question: 'Who is the expert here?'. But the spirit of the project fundamentally revolved around this question of expertise: we would collaboratively work together to become 'expert' teachers who could write our own materials in ways that were not only culturally appropriate but, more importantly, in ways that would help us take control of the production of knowledge in the writing of materials itself. Without taking ownership over the process of producing knowledge in the field (Kumaravadivelu, 1994; Pennycook \& Makoni, 2019), it would be difficult to consider our everyday acts of teaching and learning as potentially agentive in nature. To what extent should we consider our practices 'resistive' if we remained ideologically committed to being consumers, rather than producers, of knowledge? One of the key ideological constraints in teachers taking on the role of producers of knowledge - and, by implication, as theory-builders rather than recipients or users of theory - is their belief that as 'nonnative' speakers of English, they are automatically disqualified from becoming 'experts' in writing materials for the teaching and learning of English (Llurda, 2016; Tupas, 2020). The most crucial question therefore was - and this would be the subject of the paper - how could we take control of the materials writing process and, along the way, build our expertise in the area? This paper builds on the answer to this question in order to unpack the complexity of the conditioned but productive nature of teacher agency.

\section{Teacher Agency through Expertise-building}

The disavowal of 'traditional' experts does not mean we did not involve scholars from within and outside the region who are well-known for their work in curriculum development and related fields. In fact, all participants in the project early on were given the opportunity to meet in Singapore for a workshop conducted by these well-respected scholars in the field. However, we were conscious of the fact that:

Teacher training, and more acutely, ELT materials writing have often been in the hands of NSs, who at the same time have also exerted control on professional practices such as the establishment of teaching goals, approaches and methodologies, and models of language use across the profession (Llurda, 2016, p. 51).

\section{Desiring Unpredictability as an Agentive Act}

Thus, instead of working with participants to educate or train them for the latest theories and methods in language teaching and, more specifically, in the writing of ELT materials, we asked the teachers to help us unpack the process of materials design, for example by unravelling unexamined assumptions that underpin such a process. Thus, we critically examined the cultural and ideological assumptions of globalized testing competencies framework and explored the possibility of an $\mathrm{ASEAN}^{3}$ framework of language teaching and professional communication competences, an undertaking that proved to be too ideal as different institutions and countries in

\footnotetext{
${ }^{2}$ I worked with a former colleague at the National University of Singapore, Lee Kooi Cheng, who was the lead coDirector of the project.

${ }^{3}$ Association of Southeast Asian Nations
} 
the region were deploying similar terms such as 'basic proficiency' and 'advanced English language skills' with radically different assumptions given the different levels of depth and range of English language use in the region. In the workshop, we also focused on sharpening our understanding and skills in needs analysis for the purpose of identifying problems of teaching and learning specific to institutions and countries. Thus, instead of identifying theories and approaches that we could use to frame the writing of our materials - for example, should it be task-based (Liu et al. 2018), communicative (Rahman \& Pandian, 2018), language awareness-raising (Lo, 2019), grammar-oriented (Almuhammadi, 2020), or an eclectic framework (Sato \& Oyanedel, 2019)? Or should it be a World Englishes- (Sadeghpour \& Sharifian, 2019) or English as a Lingua Francaaware (Biricik Deniz et al., 2020) approach? - we sought to develop a 'grounded' problem-driven framework of curriculum development. This would be a process of writing materials and developing curricula generated by and from culturally and institutionally specific problems in language teaching and learning. Another Indonesian teacher describes the process quite succinctly based on his own experience: 'we started the project from the ground. We went to some industries and schools to investigate what our students need...' (Edu).

Consequently, the first and crucial agentive step in materials design is to de-privilege dominant and popular frameworks and, instead, develop a rigorous problems and needs analysis approach to materials writing. What are the language teaching and learning problems of students and teachers, and how best could these be addressed by materials writing? This meant that participants would require critical analytical skills in figuring out potentially eclectic solutions to these needs and problems, making their work a grounded approach to writing materials (c.f. Kuchah, 2013; Kumaravadivelu, 1994) and - this needs to be emphasized - unpredictable. The specific tracks of the process unfolded as it proceeded organically precisely because the teachers needed to map out their strategies and solutions in the light of emerging (and sometimes changing) 'new' knowledge both from their own needs analysis endeavours and from their interactions with other teachers in the project. In hindsight, many teachers found figuring out the process one of the highlights of the project, as claimed by another Indonesian participant: "What I value most about the project is "the process" to achieve good accountable work' (Mila).

The unpredictability of the process is not a disadvantage. In fact, it should be deemed a critical aspect of the process of materials writing since it proves that the writing responds to situated ecological and cultural demands of the context of teaching and learning. As an agentive tactic in our professional practice as teachers, we need to embrace the uncertainty or messiness of the process as we aim to disengage from the power of 'experts' and map alternative pathways towards collaborative expertise-building:

Uncertainty is a name for fora of collective learning. It is an intimidating prospects - to experiment, to let go, to try to unlearn habits of thought and practice - but whatever the limits it might place on responsible learning, it also, for us at least, promises an exciting and new set of possibilities (Jazeel \& McFarlane, 2010, p. 120).

\section{Listening actively as an agentive act}

What is important to emphasize in our specific blueprint of problem-focused needs analysis is the agentive act of active listening (Whitney et al., 2002; Elisha-Primo et al., 2015). The teachers 
shared - and this should not be unfamiliar to teachers in similar spaces of the geopolitics of knowledge - that teacher training programs in the region would include well-funded workshops and seminars featuring 'experts' flown in a day before the activity and would usually leave the place immediately after their lectures were done. The goal mainly was to introduce the 'newest' and 'best' practices in the field, even if decades-old research has shown that such modes of teacher training were barely effective since what teachers would have learned could not be applied when they returned to their own classrooms and institutions (Cruz Arcila, 2018; Hu, 2002; Chowdhury \& Le Ha, 2008). Alternatively, needs analysis needed to be seen not simply as a process of accumulating information but, more importantly, as an opportunity to actively listen to multiple even conflicting -- voices inside and outside the classroom, develop ways to systematically map out what has been learned by listening, and respond to these learnings in the form of localized elucidation and solutions to problems and needs of the specific contexts of teaching and learning.

Consequently, teachers needed to listen not only to students, co-teachers, and administrators, but also to industry players who had specific knowledge and skills sets in mind for their own respective workplaces. Thus, industry players in banking, call centres, IT, and tourism (among a few others), were invited to speak with teachers in several occasions throughout the duration of the project. Similarly, active listening in the project also involved interacting with - and thus, learning from - fellow participants as they too had actively listened to stakeholders in their own cultural and institutional contexts. The structure of collaborative expertise-building in the project, thus, needed to account for intercultural communication and exchange as teachers shared findings from their own needs analyses and conducted workshops for each other. This meant institutional sharing and 'listening' visits within and across countries involved in the project. In other words, groups of teachers from different institutions within the same country met several times (for example, in Hanoi or Can Tho in Vietnam) to listen to and learn from each other and, in later stages, critique each other materials. Several teachers - especially those with exemplary findings or materials -were invited to visit other countries for similar sharing and listening workshops for fellow participants. Thus, teachers from Singapore, Indonesia and Vietnam visited Iloilo City in the Philippines to meet and work with all participants in the Philippines. This would be replicated in other countries as well. If we assume that dialogues are always intercultural in nature -- race, gender, class, age, linguistic affiliation, and so on, are cultural attributes that impact the shape and content of communication (Nakayama \& Halualani, 2010) -- then listening to each other who come from different institutions and countries is central to expertise-building and, for that matter, teacher agency:

Ultimately, the very real danger posed by cultural power must be countered by the willingness of actors to listen receptively to each other, in order to understand other perspectives before criticizing them. Such receptive listening assumes that participants believe that they have something to learn from each other, which in turn presupposes the openness and trust that enable intercultural dialogue in the first place (James, 1999, p. 598).

What this showed was that, while teachers needed to respond to specific demands of teaching and learning, 'localised' solutions did not mean myopic solutions. There is a need to listen to each other because a 'local' outlook must be grounded in the material realities of teaching and learning which may also be shared by others in other contexts of teaching and learning. This would be the cultural genesis of collaborative expertise-building, where becoming 'experts' is generated 
Teacher Agency through Collaborative Expertise-buiding

through listening to what we referred to above as complex and conflicted voices of those with stakes in teaching and learning, and those with whom teachers share similar experiences and material realities. Thus, active listening serves as an agentive strategy of teachers in dealing with the massively conditioned nature of their work as materials writers and, more broadly, curriculum developers.

\section{Finding spaces of transformation as an agentive act}

In today's globalized world, where 'multicultural' and 'diverse' are used to help describe it, it is nevertheless important to note that in interactions between people in intra-national and transnational contexts "little or no emphasis is placed on listening in general, let alone on intercultural listening" (Beall, 2010, p. 226). Thus, active listening as described above should be embedded in lifelong collaborative expertise-building. In other words, it should not happen only when teachers attend workshops or training sessions. When the teacher respondents in the project returned to their respective classrooms, they revised their materials and tested them with their students and their colleagues for the purpose of receiving more feedback to sharpen the effectiveness of the materials. In the process, however, this commitment to listening to different, even conflicted, voices for the purpose of teacher self-improvement and further classroom effectiveness has accomplished far more profound impact on the teachers: a greater awareness of their power as teachers to initiate change in and outside the classroom. They have gradually taken ownership over their own choices (see examples below), not even only in the writing of materials for their own use, but in all other aspects of their teaching as well. At the start of the project, one of the key questions tackled during the first workshop for all teacher participants was about the nature of 'capability-building' for the purpose of collaborative expertise-building: 'Who decides?' As the project progressed, especially as the teachers drew confidence from listening to and learning from each other, it has become increasingly clear to everyone that teachers should be the key decision-makers in the classroom. This goes with a caveat, of course: that decision-making involved taking ownership over the production of knowledge in the field. This meant the generation of knowledge about the specific needs of students, teachers and institutions which, we have seen, has been due to the teachers' collaborative work through active listening and the embrace of unpredictability in the process.

One clear example can be gleaned through a comment by one of the teachers from Vietnam who, after the post-writing workshop (one of the last activities of the project), wrote this succinct but profoundly relevant feedback: 'We thank KC and Ruanni [co-Project Directors) for all the feedback [during this specific workshop] but we know what is the local context so we should come together more often as a team' (Ha). The teacher here signalled that while feedback from us was appreciated, they had better understanding of the local context, and that the way forward was to continue to collaboratively work with fellow teachers to produce their own materials. There is much to unpack from this statement, but what we see here relevant to our paper is the teacher's self-awareness of her right to control the production of knowledge for the purpose of writing materials for her own institutional and cultural context. There is, nevertheless, still an acknowledgement of the need to continue the conversation and listen to each other, thus the need to 'come together more often as a team.' 
Consequently, for teachers in the project, the greatest challenge now was how to locate their newfound agency within the limits of their own institutional and cultural contexts. That is, teacher agency does not simply mean awareness of one's capacity to control the structure of knowledge production, for example in materials writing, because this will result in what we have described above as idealized but naïve understanding of one's nuanced positionality vis-à-vis cultural, political and socioeconomic conditions which limit, shape and/or control one's practice of profession. Teacher agency, in fact, inscribes in itself a self-awareness of the existence of these conditions within which one's capacity to act on the world operates. I describe some of these tensions between structure and agency in earlier work on the project (Tupas, 2020; 2021), but also on general theoretical dialogues on the topic (Tupas, 2004; 2010), but the common point with conceptualizing these tensions as constitutive of teacher agency itself is that it actually allows teachers to find spaces of transformation or change amidst conditions of unfreedom. In other words, an awareness of one's capacity to act -- and limited capacity to act -- on the world opens up opportunities to earnestly look for concrete spaces to initiate reforms and change in one's own context.

An 'extreme' case during the project was the experience of one institution in Vietnam (Tupas, 2021). Having taken control over the production of their materials for students, they nevertheless realistically needed to navigate the institutional demands for the use of particular kinds of textbooks. It was clear, according to them, that there was no room for materials they produced on their own to find their way into the classroom because the ministry had its own specifications for what textbooks should be used in the light of its blanket endorsement of the Common European Framework (CEFR) (see Van Huy et al., 2016). Through dialogues between themselves, they actually found a rather utterly simple way to take these materials into the classroom without violating any institutional requirement: to introduce them as 'supplementary' materials. This way, without labelling them as required reading, the teachers worked within institutional limits but still found a space for reform in terms of providing teachers and students a broader range of content and, by implication, more culturally appropriate materials, in the English language classroom. The teachers' emerging understanding of themselves as experts in materials writing opened up spaces for them to explore ways to introduce new materials in the classroom despite their earlier misconception that educational policies are irreversible and cannot be outmanoeuvred politically and ideologically.

Another context to discuss the complex dynamics of teacher agency is the experience of one institution in the Philippines (Tupas, 2021), although it was of a radically different nature. This institution was a politically committed institution with a strong liberal arts foundation. Thus, the teachers in the project were broadly opposed to a 'market-driven' understanding of materials design (see Musa et al., 2012). Having undertaken similar listening exercises described above, the picture they needed to confront was one that saw most of their graduates going into the call center industry. Teacher agency could be gleaned through how the teachers themselves knew they could control the production of materials in ways that would take a unique shape never seen in the institution before: materials that would surface specific work-related language needs but worked out within a syllabus that allowed teachers and students to unpack the problematic nature of such market-driven needs in the first place. In a sense, the teachers wanted to teach their students the skills necessary for the workplace but also sought to let the student gain a critically-aware understanding of the skills as fleeting - indeed, these are what the market needs 'at the moment' 
(Musa et al., 2012) - as opposed to more 'universal' skills such as critical thinking (Zakaria, 2015). Similar to the Vietnamese case above, this was a case of teachers exploring reforms in the curriculum within conditions that hugely help determine the shape of such reforms. These examples operationalize the workings of teacher agency which we have repeatedly described not only as one's empowered capacity to act on the world within which are conditions which shape such an act but, more importantly as an accomplishment of acts of taking control of producing knowledge for one's professional practice.

\section{Conclusion}

"In language education," according to Van Huy et al. (2016), "there is a growing interest from many state-nations to borrow global policies and dump them into their local contexts for implementation" (p. 79). In the context of this paper, I hope to have shown how this politics of knowledge production operationalizes the unequal production of knowledge in materials design in Southeast Asia. This structural configuration of materials design serves as the broad conditioning framework for teachers' agentive acts. While Van Huy et al. (2016) refer to conflicted individual responses to top-down policy impositions and, by extension, broad political, cultural and socioeconomic conditions of unfreedom, as "internal struggles" (p. 80) of teachers to make sense of the various roles they play in their institutions, in this paper I re-frame these struggles as constitutive of the conflicted nature of teacher agency itself. That is, what teachers experience as struggles from within could actually be the operationalization of teacher agency: the individual teacher takes on the structure in order to make changes but such changes work within conditions generated by the structure itself. In this sense, teacher agency is generative or productive: it is conscious of its limits while it pushes these limits to carve out new spaces for "transforming the situations of exclusion and underachievement of some learners" (Pantić, 2015, p. 760).

This conception of teacher agency does not fall into the trap of characterizing teachers as perpetually bound within conditions of unfreedom without any possibility of transcending these conditions themselves. In fact, although extremely difficult under these times of capitalist and neoliberal globalization, breaking down the structure and the conditions that it generates is always a possibility except that one cannot naively believe that it can be done by stepping outside these overpowering conditions. This is not possible as the school itself is an institution of power imbricated within conditions and discourses of global coloniality and neoliberal globalization (Escobar, 2004). This means that educational institutions have been constantly pressured to reinvent themselves as exemplars of neoliberal ideals (Olssen \& Peters, 2005) - for example, institutions as generators of knowledge capitalism as they train students to become workers for capital, business and industries, with emphasis on performativity and the need for greater surveillance and assessment of teachers' work.

For Olssen \& Peters (2005), 'education wars' best describe the struggle of educational systems today, but it is a "struggle not only over the meaning and value of knowledge both internationally and locally, but also over the public means of knowledge production" (p. 340). This paper has argued that such a struggle - among English language educators at least - necessitates teachers' control of the structure of knowledge production in the writing of materials. Teacher agency 
emerges from this kind of struggle and makes teaching a persistently hopeful endeavour despite the overwhelming power of political, cultural and socioeconomic forces beyond our control.

\section{References}

Al Hosni, J. K. (2015). Globalization and the linguistic imperialism of the English language. Arab World English Journal (AWEJ), 6(1), 298-308.

Almuhammadi, A. (2020). Teaching grammar: Professional needs of Saudi EFL instructors. International Journal of English Linguistics, 10(3), 14-20.

Beall, M. L. (2010). Perspectives on intercultural listening. In A. D. Wolvin (ed.), Listening and human communication in the 21st century (pp. 225-238). UK: Wiley-Blackwell.

Biesta, G., Priestley, M., \& Robinson, S. (2015). The role of beliefs in teacher agency. Teachers and Teaching, 21(6), 624-640.

Biesta, G., \& Tedder, M. (2007). Agency and learning in the lifecourse: Towards an ecological perspective. Studies in the Education of Adults, 39(2), 132-149.

Biricik Deniz, E., Kemaloglu-Er, E., \& Ozkan, Y. (2020). ELF-aware pre-service teacher education: practices and perspectives. ELT Journal, 74(4), 453-462.

Butler, J. (1997). The psychic life of power. California: Stanford University Press.

Calhoun, C. (ed.) (2002). Dictionary of the social sciences. Oxford: Oxford University Press.

Campbell, E. (2012). Teacher agency in curriculum contexts. Curriculum Inquiry, 42(2), 183-

190.

Chowdhury, R., \& Le Ha, P. (2008). Reflecting on Western TESOL training and communicative language teaching: Bangladeshi teachers' voices. Asia Pacific Journal of Education, 28(3), 305-316.

Cruz Arcila, F. (2018). The wisdom of teachers' personal theories: Creative ELT practices from Colombian rural schools. Profile Issues in Teachers Professional Development, 20(2), 65-78.

Elisha-Primo, I., Sandler, S., \& Goldfrad, K. (2015). Listening to more voices: Why being heard matters. TESL-EJ, 19(3), 1-20.

Escobar, A. (2004). Beyond the Third World: Imperial globality, global coloniality and antiglobalisation social movements. Third World Quarterly, 25(1), 207-230.

Gray, J. (2002). The global coursebook in English language teaching. In D. Block and D.

Cameron (eds)., Globalization and language teaching (pp. 151-167). London and New York: Routledge.

$\mathrm{Hu}, \mathrm{G}$. (2002). Potential cultural resistance to pedagogical imports: The case of communicative language teaching in China. Language, Culture and Curriculum, 15(2), 93105.

Imants, J., \& Van der Wal, M. M. (2020). A model of teacher agency in professional development and school reform. Journal of Curriculum Studies, 52(1), 1-14.

James, M. R. (1999). Critical intercultural dialogue. Polity, 31(4), 587-607.

Jazeel, T., \& McFarlane, C. (2010). The limits of responsibility: a postcolonial politics of academic knowledge production. Transactions of the Institute of British Geographers,35(1), 109-124.

Kachru, B. B. (1986). The power and politics of English. World Englishes, 5(2-3), 121-140.

Kazemi, S. A., Asadi Aidinlou, N., \& Davatgari Asl, H. (2017). Manifestations of globalization and linguistic imperialism in English language teaching and materials preparation: Ideology in the international ELT textbooks. Research in English Language Pedagogy, 5(2), 223-246.

Kuchah, K. (2013). Context-appropriate ELT pedagogy: An investigation in Cameroonian primary schools (Doctoral dissertation, University of Warwick).

Kumaravadivelu, B. (2006). Dangerous liaison: Globalization, empire and TESOL. In J. Edge (ed.), (Re-)locating TESOL in an age of empire (pp. 1-26). Palgrave Macmillan, London. 
Kumaravadivelu, B. (1994). The postmethod condition: (E)merging strategies for second/foreign language teaching. TESOL Quarterly, 28(1), 27-48.

Lasky, S. (2005). A sociocultural approach to understanding teacher identity, agency and professional vulnerability in a context of secondary school reform. Teaching and Teacher Education, 21(8), 899-916.

Liu, Y., Mishan, F., \& Chambers, A. (2018). Investigating EFL teachers' perceptions of taskbased language teaching in higher education in China. The Language Learning Journal. doi: https://doi.org/10.1080/09571736.2018.1465110.

Llurda, E. (2016). 'Native speakers', English and ELT. The Routledge Handbook of English Language Teaching. In G. Hall (ed), The Routledge Handbook of English Language Teaching (pp. 51-63). Abingdon: Routledge.

Lo, Y. Y. (2019). Development of the beliefs and language awareness of content subject teachers in CLIL: does professional development help? International Journal of Bilingual Education and Bilingualism, 22(7), 818-832.

Musa, F., Mufti, N., Latiff, R. A., \& Amin, M. M. (2012). Project-based learning (PjBL): inculcating soft skills in 21 st century workplace. Procedia-Social and Behavioral Sciences, 59, 565-573.

Nakayama, T. K., \& Halualani, R. T. (Eds.). (2010). The handbook of critical intercultural communication. Malden, MA: Wiley-Blackwell.

Olssen, M., \& Peters, M. A. (2005). Neoliberalism, higher education and the knowledge economy: From the free market to knowledge capitalism. Journal of Education policy, 20(3), 313-345.

Pantić, N. (2015). A model for study of teacher agency for social justice. Teachers and Teaching, 21(6), 759-778.

Pennycook, A., \& Makoni, S. (2019). Innovations and challenges in applied linguistics from the global South. London \& New York: Routledge.

Priestley, M., Edwards, R., Priestley, A., \& Miller, K. (2012). Teacher agency in curriculum making: Agents of change and spaces for manoeuvre. Curriculum inquiry, 42(2), 191-214.

Rahman, M. M., \& Pandian, A. (2018). A critical investigation of English language teaching in Bangladesh: Unfulfilled expectations after two decades of communicative language teaching. English Today, 34(3), 43-49.

Sadeghpour, M., \& Sharifian, F. (2019). World Englishes in English language teaching. World Englishes, 38(1-2), 245-258.

Tao, J. \& Gao, X. (2017). Teacher agency and identity commitment in curricular reform. Teaching and Teacher Education, 63, 346-355.

Tupas, R. (2021). When localization travels to Southeast Asia: ELT curriculum development in the age of market-driven needs. In F. A. Hamied (ed)., Literacies, cultures and society towards Industrial Revolution 4.0: Reviewing policies, expanding research, enriching practices in Asia (pp. 61-80). New York: Nova Science Publishers.

Tupas, R. (2020). Experts and the geopolitics of knowledge production. Language, Culture and Society, 2(1), 116-125.

Tupas, R. (2014). The unequal production of knowledge in the sociolinguistics of Englishes. In R. Marlina, R. \& R. A. Giri (Eds.), The Pedagogy of English as an International Language: Perspectives from scholars, teachers and students (pp. 159-174). London: Springer.

Tupas, R. (2010). Which norms in everyday practice - and why? In Kirkpatrick, A. (ed.), The Routledge Handbook of World Englishes (pp. 567-579). London: Routledge.

Tupas, R. (2004). The politics of Philippine English: Neocolonialism, global politics, and the problem of postcolonialism. World Englishes, 23(1), 47-58.

Van Huy, N., Hamid, M. O., \& Renshaw, P. (2016). Language education policy enactment and individual agency: The cauldron of conflicts in policy positions in implementing the Common European Framework of Reference for languages in Vietnam. Language Problems and Language Planning, 40(1), 69-84.

Wagner, C. J., Parra, M. O., \& Proctor, C. P. (2019). Teacher agency in a multiyear 
professional development collaborative. English Teaching: Practice \& Critique.

Whitney, L., Golez, F., Nagel, G., Nieto, C., \& Nieto, C. (2002). Listening to voices of practicing teachers to examine the effectiveness of a teacher education program. Action in teacher Education, 23(4), 69-76.

Zakaria, F. (2015). In defense of a liberal education. New York: W. W. Norton \& Company. 